\title{
PEMANFAATAN IRIGASI DAN SUNGAI SEBAGAI SUMBER WISATA LOKAL AIR DAN KULINER DESA BINCAU
}

\section{Muhammad Yurbani}

Program Studi Pendidikan IPS, Fakultas FKIP, Universitas Lambung Mangkurat

E-mail: muhammadyurbani8@gmail.com

\begin{tabular}{|l|}
\hline Abstrak \\
Inspiratif adalah kata yang sesuai untuk merepresentasikan pemanfaatan \\
irigasi di Desa Bincau. Irigasi merupakan alternatif yang sering digunakan dalam \\
mengairi lahan pertanian, sawah, dan sungai sebagai sumber cadangan air. Selama ini, \\
kita hanya terpaku oleh beberapa manfaat tersebut, tanpa mengembangkan ide baru \\
yang bermanfaat bagi kehidupan. Masyarakat Desa Bincau memiliki perspektif lain \\
dalam pengembangan hal tersebut menjadi sebuah objek wisata. Pariwisata telah \\
menjadi salah satu faktor yang dapat meningkatkan perekonomian masyarakat \\
setempat dengan memanfaatkan lingkungan sekitar. Masyarakat setempat berusaha \\
untuk mengembangkan dan mengelola pariwisata mereka. Dengan mengembangkan \\
dan mengelola pariwisata yang ada, diharapkan dapat melestarikan nilai nilai \\
kebudayaan, agama, lingkungan hidup, dan sekaligus dapat memperkenalkan keunikan \\
dan keberagaman yang dimiliki daerah tersebut. Sesuatu yang menarik dari segi \\
pariwisata adalah obyek obyek wisatanya dan jenis jenis pariwisatanya, seperti wisata \\
alam, wisata buatan dan wisata budaya. Selain menjadi pendorong pertumbuhan \\
ekonomi, pariwisata juga dapat menjadi pendorong dalam sektor pembangunan \\
lainnya, seperti sektor perkebunan, pertanian, perdagangan, perindustrian dan lain-lain. \\
Kata kunci : Kearifan Lokal, Budaya, Wisata \\
\hline
\end{tabular}

\section{PENDAHULUAN}

Kalimantan Selatan memiliki banyak potensi dan sumber daya alam yang belum dikembangkan dan dikelola secara maksimal, termasuk didalamnya di 
sektor pariwisata air dan kuliner. Oleh karena itu, perlu adanya pengembangan sektor pariwisata dalam rangka mendukung pencapaian sasaran pembangunan, sehingga perlu diupayakan pengembangan produk produk yang mempunyai keterkaitan dengan sektor pariwisata. Pengembangan kepariwisataan berkaitan erat dengan pelestarian nilai-nilai kepribadian dan pengembangan budaya bangsa, dengan memanfaatkan seluruh potensi keindahan dan kekayaan alam Indonesia. Pemanfaatan disini bukan berarti merubah secara total, tetapi lebih berarti mengelola, memanfaatkan dan melestarikan setiap potensi yang ada, dimana potensi tersebut dirangkaikan menjadi satu daya tarik wisata.

Kabupaten Banjar terkenal akan sisi religiusitas yang ada dalam kehidupan masyarakatnya di kehidupan sehari-hari. Kabupaten ini memiliki berbagai kecamatan salah satunya adalah desa Bincau. Desa ini terletak di daerah yang cukup dekat dari daerah lainnya di Martapura. Jarak antara Martapura selaku ibukota dari kabupaten Banjar dengan kawasan ini memerlukan waktu yang singkat mengingat medan dan jalanan yang dilalui dengan akses jalanan yang sudah memadai. Daerah ini memiliki cukup banyak sungai yang saling terhubung dengan irigasi yang terdapat di sekitar wilayah tersebut. Irigasi tersebut pada umumnya digunakan untuk mengaliri lahan persawahan masyarakat dan keramba yang berada di tepian sungai.

Kesadaran masyarakat terhadap lingkungan sekitar merupakan masalah pada pengembangan berkelanjutan. Satu penyebab minimnya kepedulian masyarakat terhadap lingkungan adalah membuang sampah tidak pada tempatnya, sehingga hal semacam ini banyak pihak yang saling dirugikan. Bagi wilayah bantaran sungai, membuang sampah ke sungai sangat merugikan kelangsungan sungai. (Syahrin, M. A., Syaharuddin, S., \& Rahman, A. M. (2020). Melihat besarnya manfaat dari irigasi dan keramba atau tambak ikan yang ada, masyarakat setempat berinsiatif untuk membuat sebuah tempat wisata air dan kuliner dengan mengombinasikan kedua hal tersebut. Kedua potensi sumber daya alam tersebut tentunya tidak dimiliki oleh semua daerah. Hal tersebut, memicu terciptanya sebuah ide untuk membuat objek wisata berbasis air dan kuliner dengan melibatkan kearifan lokal dari masyarakat setempat. Sebagian besar masyarakat 
Desa Bincau pada umumnya bermata pencaharian sebagai petani dan membudidayakan ikan dengan kolam tambak maupun keramba di tepian sungai.

Hal tersebut terjadi tentunya karena adanya akses air bersih dari irigasi membuat mereka dapat memanfaatkan hal tersebut dalam memutar roda perekonomian setempat. Adanya pengetahuan akan kebersihan turut mempengaruhi pemahaman sebagian masyarakat untuk tidak lagi pemanfaatan air sungai bagi aktivitas seperti mandi dan mencuci. Jika dilihat dari aspek hubungan antar manusia, perkembangan zaman sekarang ini belum memberikan pengaruh besar bagi kehidupan sosial masyarakat di bantaran sungai. (Putro, H. P. N., Jumriani, J., Darmawan, D., \& Nuryatin, S. (2020). Oleh karena itu, di bangunlah sebuah tempat dimana kuliner dan wisata air terintegrasi dalam satu tempat. Dimana dalam tempat wisata tersebut terdapat pendopo pendopo kecil yang di bangun di atas kolam atau tambak ikan, pemanfaatan keramba di tepian sungai sebagai tempat pemancingan, serta sungai sebagai sarana wisata air.

Dengan adanya objek wisata tersebut diharapkan dapat menambah pendapatan asli daerah supaya menjadi kota yang lebih maju dan berkembang dengan baik. Hal tersebut selaras dengan sebuah pernyataan bahwa manusia makhluk yang memiliki hubungan timbal balik dengan lingkungan, tentunya harus membayar dan memperhatikan bagaimana memanfaatkan lingkungan sehingga hubungan yang harmonis dapat terjadi (Abbas etal., 2015; Maunah, 2015; Nasrudin dkk., 2019; Sandoval-Rivera, 2020). Pembelajaran merupakan sesuatu perihal yang absolut untuk masyarakat. Pembelajaran merupakan jalur yan terbaik buat tingkatkan taraf kehidupan suatu generasi tidak terkecuali di Indonesia. Pendidikan merupakan jalur yang dapat dikembangkan untuk memberikan pendidikan kepada masyarakat tentang kearifan lokal di lingkungan tempat mereka tinggal dan kegunaannya sebagai pedoman kehidupan dalam berbagai aspek. Untuk mendukung hal tersebut diperlukan suatu sistem yang dapat mengatur pendidikan itu sendiri (Ilhami dkk., 2019; Ma'nawiyah dkk., 2019).

\section{METODE}


Metode yang digunakan dalam penulisan artikel ini ialah studi literatur. Studi literatur digunakan untuk mengumpulkan data atau sumber yang berkaitan dengan topik tertentu dari berbagai sumber seperti jurnal, buku, dan lainnya (Snyder, 2019). Penggunaan strategi literatur ialah dapat mengetahui masalah untuk mendapatkan ide yang menarik serta berguna, dapat membandingkan atau menjadikan pijakan karya-karya sebelumnya sebagai bahan pembantu tulisan, serta membantu menghindari kesalahan penulisan yang ada sebelumnya. StrategiStrategi pencarian literatur dilakukan melalui jurnal pada Google Scholar, buku elektronik pada Google Book, dan website google berjumlah, kata kunci pencarian berupa: Pembelajaran, Kendala belajar, Kearifan Lokal.

\section{HASIL DAN PEMBAHASAN}

Wisata adalah kegiatan perjalanan yang dilakukan oleh seseorang atau sekelompok orang dengan mengunjungi tempat tertentu untuk tujuan rekreasi, pengembangan pribadi, atau mempelajari keunikan daya tarik wisata yang dikunjungi dalam jangka waktu sementara. Pariwisata adalah berbagai macam kegiatan wisata dan didukung berbagai fasilitas serta layanan yang disediakan oleh masyarakat, pengusaha, pemerintah, dan Pemerintah Daerah. Pariwisata adalah suatu proses kepergian sementara seseorang, lebih menuju ketempat lain diluar tempat tinggalnya. Kearifan lokal merupakan karaterisitk masyarakat di suatu daerah yang harus dijaga sebagai identitas konstruktif sekaligus sebagai filter bagi berbagai aspek kebudayaan luar yang destruktif. Dalam konteks demikian, kearifan lokal dipahami sebagai warisan dari generasi ke generasi agar tidak tergerus beragam unsur-unsur kebuduyaan luar. (Jumriani, J., Mutiani, M., Putra, MAH, Syaharuddin, S., \& Abbas, EW (2021).

Masyarakat desa Bincau pada umumnya bermata pencaharian sebagai petani dan budidaya ikan dengan keramba yang ada di tepian sungai. Hal tersebut merupakan kearifan lokal yang tercipta dari adanya kesadaran masyarakat terhadap sang pencipta terhadap setiap tindakannya. Nilai nilai religiusitas yang kental dalam kota Martapura seakan turut mengalir ke berbagai daerah di kota tersebut. Mereka percaya segala tindakan yang dilakukan dengan izin sang pencipta akan membuahkan hasil yang baik dan lebih berkah atau barokah. Selain 
itu, kondisi wilayah yang dialiri aliran sungai membuat masyarakat memanfaatkan hal tersebut dengan budidaya ikan di keramba keramba yang terapung di sungai.

Debit dan arus yang terbilang sedang, memudahkan masyarakat dalam membuat keramba apung sebagai sarana dalam bubidaya ikan. Masyarakat setempat cenderung lebih mudah dalam proses budidaya mengingat ikan yang dipelihara adalah ikan endemik sungai tersebut. Potensi perairan tersebut memunculkan ide dan gagasan kreatif dari masyarakat, dimana mereka membuat tempat budidaya sebagai sumber pariwisata. Hal tersebut terlihat dari adanya penataan ruang yang rapi dan estetik sehingga memunculkan rasa penasaran bagi masyarakat yang berkunjung ke desa tersebut. Dengan adanya fasilitas pendopo dan rumah makan yang menyajikan hidangan dari hasil budidaya ikan di keramba tersebut, menjadi daya tarik tersendiri dari lingkungan sekitar desa. Kuliner merupakan satu kebutuhan utama manusia dalam kehidupan sehari-hari. Pengembangan wisata kuliner memberikan berbagai manfaat. Wisata kuliner, dapat digunakan sebagai alat untuk mengenalkan budaya lokal. Wisata kuliner juga memberikan peluang baru bagi destinasi dan alat promosi. (Ersis, W. A., Jumriani, M. A. H., \& Mutiani, M. R. N. 2021).

Kearifan lokal berfungsi sebagai stabilitas sosial dan kontrol atas berbagai aktivitas manusia yang melibatkan pemilik kehidupan dan kehidupan masyarakat. (Jumriani, J., Mutiani, M., Putra, MAH, Syaharuddin, S., \& Abbas, EW (2021). Oleh karena itu, wisata lokal ini memiliki berbagai kepentingan baik karena kepentingan ekonomi, sosial, budaya, politik, agama, kesehatan maupun kepentingan lain. Aksesbilitas menuju obyek wisata air di Desa Bincau ini sangatlah mudah ditunjang dengan keadaan jalan yang sudah beraspal tetapi petunjuk arah menuju obyeknya hanya terdapat ketika sudah memasuki wilayah Desa tersebut, sehingga membingungkan wisatawan yang baru pertama kali berkunjung kesana dan berasal dari luar daerah. Karena tidak terdapat transportasi umum, maka penggunaan kendaraan pribadi sangat disarankan, jalan menuju obyek wisata air ini dapat dilalui oleh kendaraan roda dua maupun roda empat. Jalan yang dilalui untuk menuju wisata ini sangatlah teduh dengan sisi kanan dan 
sisi kiri banyak terdapat pohon pohon rindang dan udara sejuk khas pedesaan sangat terasa sekali membuat pengunjung dapat menikmati perjalanan.

Sebagai manusia makhluk yang memiliki hubungan timbal balik dengan lingkungan tentunya harus membayar memperhatikan bagaimana memanfaatkan lingkungan agar dapat terjadi hubungan yang harmonis (Abbas et al., 2015; Maunah, 2015; Nasrudin dkk., 2019; Sandoval-Rivera, 2020). Masyarakat di sekitar obyek wisata air di desa Bincau ini belum berperan aktif dalam pengembangan pariwisata, dikarenakan kualitas SDM pariwisata bisa dikatakan masih rendah dengan tingkat pendidikan yang rata-rata hanya sebagai lulusan SLTA sehingga kurang kreatif dan inovatif dalam membangun dan mengembangan obyek wisata air dan kuliner ini. Namun masyarakat sekitar sangat mendukung pengembangan pemanfaatan irigasi sebagai penunjang wisata tersebut dijadikan sebagai tempat wisata dengan pengelolaan profesional yang nantinya dapat memberikan dampak positif ekonomi untuk mereka. Untuk saat ini, masyarakat hanya sebatas mendirikan warung warung tenda untuk berjualan makanan ataupun minuman kepada pengunjung obyek wisata tersebut.

Pengelolaan objek wisata air dan kuliner ini masih sebatas di kelola oleh pemerintah desa dan masyarakat setempat. Pengelolaannya masih dilakukan secara sederhana, seperti penjagaan loket dan penjagaan parkir yang hanya di lakukan ketika pengunjung tiba. Belum dikelolanya obyek wisata secara profesional membuat fasilitas sarana dan prasarana pendukung pariwisata terlihat seperti kurang dijaga dan dirawat dengan baik sehingga pengelolaannya perlu ditingkatkan lagi dan peran dari pemerintah kabupaten Banjar sangat dibutuhkan untuk lebih memaksimalkan pembangunan dan pengelolaan untuk menarik wisatawan untuk berkunjung ke obyek wisata air dan kuliner Bincau ini.

Fasilitas yang ada di obyek wisata air di desa Bincau masih tergolong minim dan seadanya, hanya terdapat beberapa tenda warung makan yang dibangun secara mandiri oleh masyarakat, beberapa gazebo untuk tempat makan dan berteduh, 2 toilet dan 2 kamar ganti serta 1 mushola lengkap dengan alat sholat. Saat saya berkunjung ke obyek wisata air di desa Bincau ini terdapat beberapa aturan yang dibuat oleh masyarakat setempat dan pengelola dan sudah menjadi aturan yang harus dipatuhi oleh siapa saja yang berkunjung ke obyek 
wisata tersebut. Beberapa aturan yang ada ditempat itu seperti tidak boleh membuang sampah sembarangan, harus parkir di tempat yang telah di sediakan dan tidak boleh turun ke bawah sungai saat cuaca mendung dan turun hujan. Peraturan tersebut dibuat untuk menciptakan kondisi obyek wisata yang kondusif, bersih dan menjaga keselamatan pengunjung.

Wisatawan yang berkunjung ke obyek wisata ini mayoritas adalah wisatawan lokal atau berasal dari dalam kabupaten Banjar, seperti dari Banjarmasin, Gambut, Banjarbaru, dan daerah Hulu Sungai. Dan tidak setiap harinya obyek wisata air dan kuliner di desa Bincau ini ramai dikunjungi, namun ramai dikunjungi saat musim liburan tiba atau di hari sabtu dan minggu. Pengunjung yang datang sebagian besar adalah anak muda tetapi pangsa pasar yang dituju oleh pengelola yaitu dari semua kalangan mulai dari anak anak sampai orang tua.

Promosi objek wisata air dan kuliner di desa Bincau ini masih belum dilakukan secara maksimal. Saat saya berkunjung ke objek wisata ini tidak ada papan maupun spanduk untuk mempromosikan obyek wisata air dan kuliner ini. Saya hanya menjumpai promosi berupa plakat kayu kecil yang bertuliskan nama dari setiap objek wisata tersebut. Selain itu wisatawan luar daerah mengetahui objek wisata air dan kuliner desa Bincau ini dari saudara maupun teman serta dari media sosial, sehingga dapat dikatakan bahwa word of mouth dan kekuatan media sosial dapat menjadi senjata yang ampuh untuk lebih memperkenalkan dan mempromosikan obyek wisata air dan kuliner desa Bincau kepada masyarakat luas.

Sumber daya manusia merupakan salah satu kunci dalam pembangunan pariwisata. Eksistensi sebuah obyek wisata di tentukan oleh SDM yang berkualitas, kreatif dan inovatif, dengan begitu berpotensi membawa pariwisata di daerahnya berkembang dengan baik. Sebagai industri jasa, kepuasan dari wisatawan merupakan tujuan utama yang harus selalu di perhatikan sehingga menjadi nilai lebih dalam pertumbuhan pariwisata di masa yang akan datang. Namun sayangnya hal tersebut belum di miliki oleh SDM yang ada di desa Bincau. Alasan paling mendasar adalah pengetahuan masyarakat desa tentang 
bagaimana mengelola dan mengembangkan objek wisata air dan kuliner Bincau ini, dikarenakan tingkat pendidikan di desa tersebut tergolong rendah.

Masyarakat memang sudah banyak yang menyadari akan potensi yang di miliki oleh objek wisata tersebut, hanya saja pengelolaannya belum dilakukan secara maksimal. Kurangnya sosialisasi juga berpengaruh pada rendahnya minat dari masyarakat untuk bekerjasama dengan baik guna membangun dan mengembangkan objek wisata tersebut. Masyarakat setempat berperan penting dalam mengelola, mengembangkan dan ikut dalam pembangunan objek wisata air dan kuliner Bincau, akan tetapi minimnya pengetahuan dan kurangnya sadar wisata tentang pentingnya pengembangan obyek wisata menjadi kendala dalam mengembangkan obyek wisata ini. Oleh karena itu, masyarakat perlu bimbingan khusus tentang pentingnya membangun obyek pariwisata di lingkungnnya agar dapat meningkatkan pengetahuan dan ekonomi masyarakat setempat.

\section{IV.SIMPULAN}

Objek wisata air dan kuliner desa Bincau merupakan obyek wisata yang menyajikan keindahan alam yang unik dan menarik. Keindahan alamnya yang masih asri dan sangat segar udaranya menambah kesejukan dan membuat betah para wisatawan yang berkunjung. Keberadaan objek wisata ini sudah cukup lama namun potensi yang dimiliki baru dikembangkan ke masyarakat luas. Kegiatan berfoto dengan latar sungai dan keramba di tepian sungai serta aktivitas lainnya seperti memancing dan menaiki perahu bebek menjadi aktifitas unggulan yang dijadikan sebagai daya tarik utama obyek wisata ini.

Sarana dan prasarana yang belum terlalu memadai tetapi sudah dapat digunakan seperti gazebo, toilet, kamar ganti dan beberapa warung swadaya masyarakat setempat dan aksesbilitas menuju objek wisata air dan kuliner Bincau terbilang mudah siap menunjang kegiatan aktifitas wisata. Pengelolaannya yang masih dikelola oleh masyarakat setempat membuat objek wisata air dan kuliner ini masih terbilang seadanya. Saya berharap objek wisata air dan kuliner Bincau ini dapat di berikan perhatian oleh pemerintah setempat dengan segera, agar dapat mengembangkan pembangunan wisata ini menjadi lebih baik dengan menambah 
serta memperbaiki insfrastruktur maupun sarana prasarana yang digunakan untuk kegiatan pariwisata. 


\section{DAFTAR PUSTAKA}

Abbas, E. W. (2018). Penguatan Pendidikan IPS Di Tengah Isu-Isu Global. Program Studi Pendidikan IPS FKIP ULM.

Ersis, W. A., Jumriani, M. A. H., \& Mutiani, M. R. N. (2021). PERAN PENGUSAHA KULINER DI KAWASAN KULINER BANUA ANYAR BAGI PENGEMBANGAN PARIWISATA DI KOTA BANJARMASIN. In PROSIDING SEMINAR NASIONAL LINGKUNGAN LAHAN BASAH (Vol. 6, No. 1).

Ilhami, A., Riandi, R., \& Sriyati, S. (2019). Implementation of science learning with local wisdom approach toward environmental literacy.

Jumriani, J., Mutiani, M., Putra, MAH, Syaharuddin, S., \& Abbas, EW (2021). Urgensi Muatan Kearifan Lokal dalam Pembelajaran IPS: Tinjauan Pustaka. Jurnal Inovasi Ilmu Sosial , 2 (2), 103-109.

Jumriani, J., Mutiani, M., Putra, M. A. H., Syaharuddin, S., \& Abbas, E. W. (2021). The Urgency of Local Wisdom Content in Social Studies Learning: Literature Review.

Ma'nawiyah, M., Sarbaini, S., \& Syaharuddin, S. (2019). IMPLEMENTASI NILAI PEDULI LINGKUNGAN DI SMP NEGERI 27 BANJARMASIN.

Putro, H. P. N., Jumriani, J., Darmawan, D., \& Nuryatin, S. (2020). Social Life of the Community: Perspective of Riverbanks Community in Sungai Jingah, Banjarmasin. The Kalimantan Social Studies Journal, 1(2), 151-158.

Snyder, H. (2019). Literature Review As A Research Methodology: An Overview And Guidelines. Journal of Business Research, 104, 333-339.

Syahrin, M. A., Syaharuddin, S., \& Rahman, A. M. (2020). Environmental Awareness of Kampung Hijau Society, Sungai Bilu Banjarmasin. The Kalimantan Social Studies Journal, 1(2), 191-200.

Syaharuddin, S. (2020). Pembelajaran Masa Pandemi: Dari Konvensional Ke Daring. Pembelajaran Masa Pandemi: Dari Konvensional Ke Daring. 
